IRA-International Journal of Technology \& Engineering ISSN 2455-4480

Proceedings of the

International Conference on Science \&

Engineering for Sustainable Development (2017)

Pg. no.160-170

Published by: Institute of Research Advances

https://research-advances.org/index.php/IRAJTE

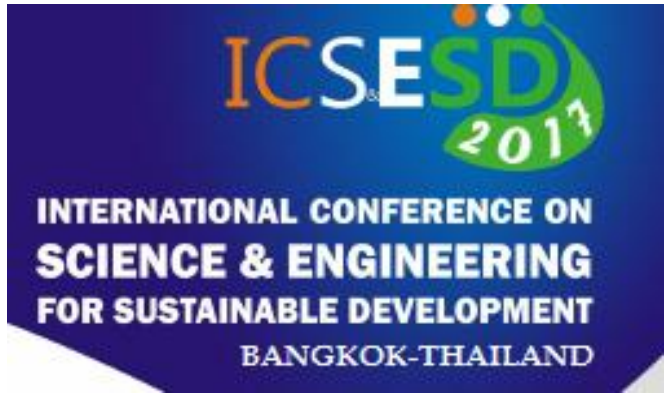

\title{
Study of Effect of Various Process Parameters on the Performance of Chimney Operated Solar Power Plant \\ P.J.Bansod ${ }^{1}$, Dr.S.B.Thakre ${ }^{2}$,N.A.Wankhade ${ }^{3}$
}

${ }^{1} \mathrm{PhD}$ Scholar, Department of Mechanical Engineering, PRMIT\&R Badnera, Amravati University, India.

${ }^{2}$ Professor, Department of Mechanical Engineering, PRMIT\&R Badnera, Amravati University, India.

${ }^{3}$ Associate Professor, Department of Mechanical Engineering, PRMIT\&R Badnera, Amravati University, India.

Type of Review: Originality Check \& Peer Review under the responsibility of the Scientific Committee of the Conference and The Institution of Engineers (India). DOI: http://dx.doi.org/10.21013/jte.ICSESD201716

\section{How to cite this paper:}

Bansod, P., Thakre, S., Wankhade, N. (2017). Study of Effect of Various Process Parameters on the Performance of Chimney Operated Solar Power Plant. Proceedings of the International Conference on Science \& Engineering for Sustainable Development (2017), 160-170. doi: http://dx.doi.org/10.21013/jte.ICSESD201716

(C) International Conference on Science \& Engineering for Sustainable Development \& The Institution of Engineers (India).

\section{(cc) BY-NC}

This work is licensed under a Creative Commons Attribution-Non Commercial 4.0 International License subject to proper citation to the publication source of the work.

Disclaimer: The conference papers as published by the Institute of Research Advances (IRA) are the views and opinions of their respective authors and are not the views or opinions of the IRA. The IRA disclaims of any harm or loss caused due to the published content to any party. 


\section{ABSTRACT}

Conventional energy sources like coal and oil used for power generation causes various environmental problems like creating pollution and creating ecological imbalance. These sources are also depleting due to lesser use of alternative resources. Chimney operated solar power plant is one of the best alternative which can be used to produce power in large capacity with the use of solar energy. It consist of very few number of parts like turbine, collector and chimney. This paper consist of study of effect of different process parameters on the performance this chimney operated solar power plant. A small prototype model of this power plant is fabricated which has collector of $1.8 \mathrm{~m}$ diameter and chimney of maximum height of $2.0 \mathrm{~m}$. D.C motor with small generator and blades is used as turbine to get power output. The various process parameters like temperature, pressure, velocity are used to determine power output and efficiency of power plant. Numerous mathematical correlations were used to correlate these input and output parameters. The effect of chimney height on these parameters was studied. It was determined that temperature and velocity are the important parameters which improves the performance of solar chimney power plant along with chimney height and collector diameter.

Keywords: Collector, Chimney, Turbine, Generator, Prototype, D.C .Motor, mass low rate.

\section{Introduction}

In recent time the available energy sources like coal, fuel and nuclear are providing various challenges. The reserve of these sources are very limited now. Numerous environmental impacts like global warming, acid rain, ozone layer depletion are causing of various dieses to human being. The cost of these conventional sources is also increasing day by day. There is constant requirement to use such a device for energy generation and other purposes which can be based on nonconventional sources like, solar, water, wind, tidal, biomass and geothermal energy. These energy sources can be used extensively for power generation and can solve all the problems related to environment[1].

Solar energy operated chimney power plant was old technology of power generation but it was not explored commercially. Numerous research were carried out on solar chimney technology by various researchers. In the early years a big tower which was popularly called as smock jack was sketched by Leonardo Da Vinci way back in the year 1500 [2]. The idea of using solar energy was also proposed by Gunther in 1903. He suggested a skirt like structure connected by brick work at bottom and passing hot air at the height of $63.87 \mathrm{~m}$. cylindrical structure[3,4].The experimental work on solar chimney was first done in Manzanares Spain in 1981with the help of government of Germany. The tower height was 194.6 $\mathrm{m}$, tower radios was $5.08 \mathrm{~m}$ and collector radius was $122 \mathrm{~m}$. The plant run for nearly three years and had produced power of $50 \mathrm{kw}$. The plant was failure due to improper support provided and was collapsed due heavy wind flow [5,6].Z.D. Chen et al. had carried an experimental investigation of a solar chimney model with uniform wall heat flux on a chimney wall with variable chimney gap to height ratio and different heat flux and inclination angles which given the maximum air flow rate at specific angle and specific height to gap ratio[7]. Counter rotating turbines was suggested by F.Denantes et al. for solar chimney power plant. Two counter rotating turbines one with inlet guide wanes and the other without guide vanes were compared to a single runner system. They also demonstrated advantageous operational conditions of counter rotating turbines[8]. Xinping Zhou et al. had performed simulation of pilot solar chimney equipment and also analyzed the chimney height. They obtained power output in steady state for different global solar radiation intensity, collector area and chimney height. The Manzanares prototype was taken as reference. They predicted that optimal chimney height for maximum power output which increases with large collector radius[9,10].Jorg Schlaich et al. presents the theory, practical applications and economy of solar updraft towers. They concluded that the thermodynamic efficiency of plant depends on chimney height and as the plant is constructed from easily available material such as concrete and glass and large space requirements, it is possible to construct such plants in desert areas there is always lack of 
electricity in summer in these areas. [11]. Koonsrisuk et al. had studied and developed theory on constructal solar chimney configuration to increase the power production over the area occupied by the plant. They predicted that the pressure drop at the collector inlet and at the transition section between collector and chimney are negligible and the friction losses in the collector can be neglected when the svelteness of the entire flow architecture is greater than approximately by 6[12]. Fei Cao et al. had investigated the performance analysis of conventional and sloped solar chimney power plants in China. They also carried economic analysis by using heat transfer model of solar chimney. They also analyzed power generation from solar chimney at different latitudes. The techno economical analysis was performed by selecting Lanzhou, China for case study $[13,14]$. Cristiana Maia et al. had performed the theoretical evaluation of the influence of geometric parameters on the behavior of the airflow in solar chimney. They performed an analytical and numerical study of the unsteady air flow inside the solar chimney. The model of solar chimney was developed with operational and geometric configurations different from those found in experimental prototype. From the analysis they concluded that the height and diameter of solar chimney are important physical variables for solar chimney design[15]. Alibakhsh Kasaeian et al. had done simulation and optimization of geometric parameters of solar chimney in Tehran. They presented a fundamental model of fluid flow and plant performance was evaluated with the operational and geometric configurations. It was found that the velocity magnitude can be raised to 4-25 $\%$ in different cases considered and also indicated that height and diameter of chimney are the most important physical variables for solar chimney design_[16]. Bernardes et al. had analysed heat transfer coefficients applicable to solar chimney power plant collectors. Different methods are provided to calculate the heat fluxes in the collector and their effect on solar chimney performance[17]. Shadi Kalash et al. had done experimental investigation of sloped solar updraft power plant. Glass, air and absorption layer temperature were measured with the help of average monthly recorded values of solar radiation and ambient temperature. The difference between the ambient temperature and chimney inlet temperature was almost same in winter and summer seasons which gives the advantage of using inclined solar collector[18]. Peng-hua Guo et al. had done performance analysis of solar chimney power plant in China. The theoretical model was developed by taking into account the hourly variation of solar radiation. They analyzed the effect of the chimney and collector radii on the power output of solar chimney. The results showed that power output varied as per season[19].P.J. Cotton et al. had predicted the effect of canopy profile on solar thermal chimney performance. The analytical model was developed to describe the thermodynamics of the collector. A new collector profile with a partially sloped canopy was proposed. It was proposed that, for the ease of construction and reduction of associated costs, canopy can be build in stepped annular flat sections with only a minor loss in performance $\lceil 20]$.
Nomenclature
m Mass flow rate $(\mathrm{kg} / \mathrm{s})$
$\mathrm{U}$ Heat loss co-efficient $\left(\mathrm{w} / \mathrm{m}^{2} \mathrm{k}\right)$
$\Delta \mathrm{T}$ Temperature rise between collector inflow and out flow
$\rho_{c}$ Density of hot air through chimney $\left(\mathrm{Kg} / \mathrm{m}^{3}\right)$
$\rho_{a m b}$ Density of ambient air $\mathrm{kg} / \mathrm{m}^{3}$
$\mathrm{A}_{\mathrm{c}}$ Cross - sectional area of solar chimney $\left(\mathrm{m}^{2}\right)$
$\rho_{c h}$ Density of hot air inside the chimney $\mathrm{kg} / \mathrm{m}^{3}$.
$\mathrm{V}_{\mathrm{ci}}$ Inlet air velocity of solar chimney $(\mathrm{m} / \mathrm{s})$ 


\section{Working Principle of Solar Chimney}

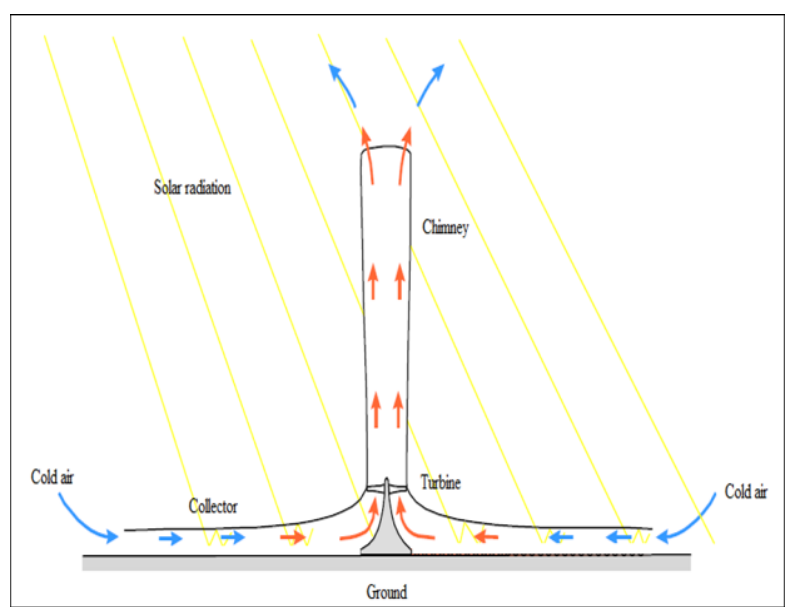

Fig .1.Working Principle of solar chimney

Fig.1 illustrates working principle of solar chimney. Solar chimney power plant takes radiation from Sun and converts it into power with the help of three familiar principles that are chimney, wind flow through turbine and green house effect of collector in proper way. Collector is made of glass roof takes hot air produce by the Sun. The glass roof and strike by two types of radiation: diffuse and direct radiation where specific fraction of energy get absorbed some get transmitted and remaining get reflected. These quantities depend upon angle of incidence and glass optical characteristics [21].

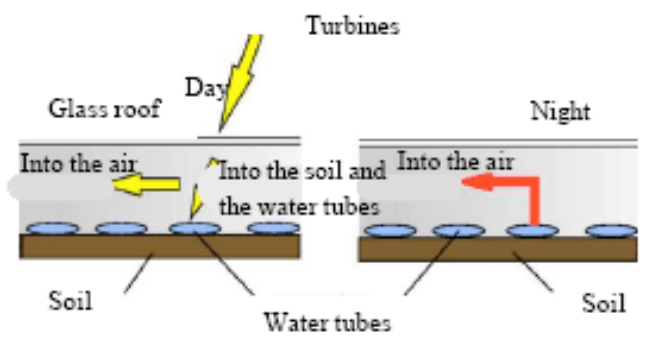

Fig. 2. Filled sealed water tube under collector

The air enters from bottom surface of the collector which is kept at some distance from ground. This heated air rises due to density difference from inlet to outlet and flow out of chimney due to buoyancy force. When this heated air flows out it passes through the blades of turbine coupled with generator, it harnesses the kinetic energy in the moving air and convert it into electrical energy [22]. As shown in Fig.2 for improving the efficiency of solar chimney packed steel container with water are placed under collector which absorbs heat during day time and during night leave the heat to the collector. In this way continuous working of solar chimney is possible for 24 hours duration a day also which can also improve the efficiency of solar chimney [23]. 


\section{Experimental setup}

The main aim of this experimentation was to test the viability of solar chimney in central region of India. The month of May of summer season which is hottest month in this region was selected for conducting the experimentation so that to get maximum power output from selected size of solar chimney.

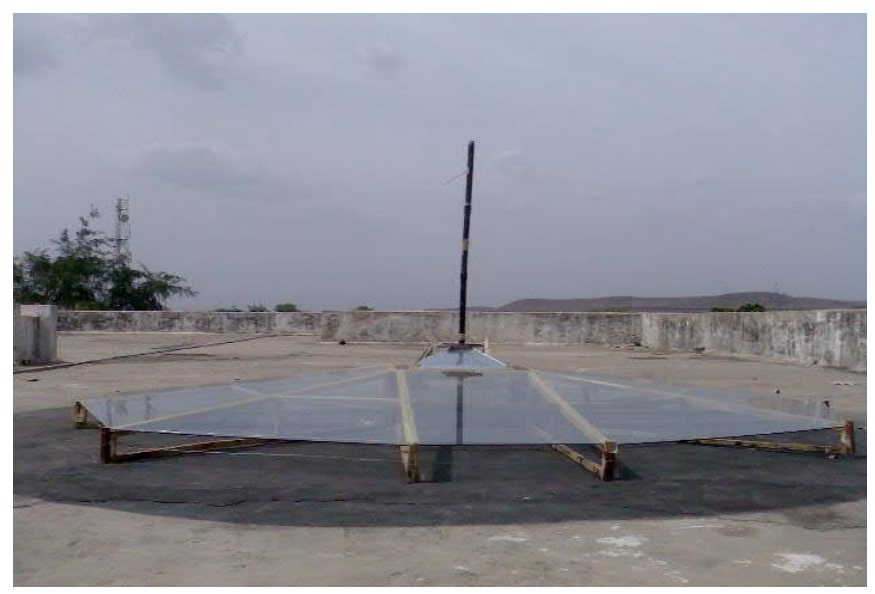

Fig. 3. Experimental setup of solar chimney

A small prototype model of solar power plant was made by the assembly of three main parts: collector, chimney and turbine. Collector was made up of glass material and was fabricated in trapezoidal shape with the help of wooden frames to support the glass structure. The diameter of collector was $1.8 \mathrm{~m}$. A sheet metal dome was provided at the top of the collector to support chimney in the collector. Collector was provided at suitable height from ground on wooden frame so that hot air can enter from all sides of the collector. Turbine in the form of small blades with 3V D.C generator was mounted at bottom of the collector. A cylindrical chimney of $0.038 \mathrm{~m}$ diameter and different heights varies from $0.5 \mathrm{~m}$ to $2.0 \mathrm{~m}$ are used. This cylindrical chimney was properly supported in the collector and sealed with Teflon tape to prevent leakage of hot air from the joint as gas tight joint is required to get maximum output from this plant. The selected input parameters are measured with the help various equipments. Temperature was measured with the help of PT-100 thermocouple. A pyrometer of Lutron make Am-4201with maximum capacity of $25 \mathrm{~m} / \mathrm{s}$ was used to measure velocity of air flow. Digital thermometer was used to measure surface temperature and inlet air temperature. Air density was measured with the help of Aerometer. The range of this instrument was from 0 to $2 \mathrm{~g} / \mathrm{cm}^{3}$. The approximate height of instrument was $715 \mathrm{~mm}$ and $35 \mathrm{~mm}$ in diameter. The experimental setup of solar chimney power plant is shown in Fig. 3. This setup was placed on top of the building to get maximum power output and to absorb maximum solar radiation from all the directions. To improve the efficiency of this power plant a black coating of paint was provided on the surface of the terrace so as to absorb maximum amount of solar radiation incident on the surface. Mathematical correlations are used to connect I/P and O/P parameters.

\section{Mathematical modeling}

The power output of solar chimney depends on its size as well as outside weather conditions. The input parameters are connected to output parameters with various correlations which are given below.

A) The collector efficiency

The steady state collector efficiency is expressed as the ratio of heat output $Q$ to the G times collector area. 


$$
\eta_{\text {coll }}=\frac{Q}{G \cdot A_{\text {coll }}}
$$

Heat output can be expressed as product of mass flow rate, specific heat at constant pressure and rise in air temperature.

$$
Q=\dot{m} C_{P a} \Delta T
$$

Where, $\dot{m}$ denotes the mass flow rate of hot air passing through the solar chimney and can be calculated as

$$
\dot{m}=\rho_{c} A_{c} V_{c i}
$$

Also,

heat balance for collector can be expressed as

$$
Q=\alpha A_{\text {coll }} \cdot G-U \Delta T A_{\text {coll }} \text {. }
$$

From equation (1) and (4), the collector efficiency can also be expressed as

$$
\begin{gathered}
\eta_{\text {coll }}=\frac{\alpha \cdot A_{\text {coll }} \cdot G-U \cdot \Delta T \cdot A_{\text {coll }}}{G \cdot A_{\text {coll }}} \\
\eta_{\text {coll }}=\alpha-\frac{U \cdot \Delta T}{G}
\end{gathered}
$$

B) Chimney Efficie ncy

The chimney efficiency is given by

$$
\eta_{c h}=\frac{g H c}{C_{p a} \mathrm{~T}_{\mathrm{a}}}
$$

C) Turbine Power output

From available pressure drop across the turbine, power output by turbine is given by

$$
\mathrm{P}_{\mathrm{wt}}=\Delta \mathrm{P}_{\mathrm{s}} \mathrm{V}_{\mathrm{ci}} \mathrm{A}_{\mathrm{c}}
$$

D)Turbine conversion efficiency

The turbine conversion efficiency is the ratio of power output from turbine to energy input rate[23,24,25,26].

$$
\eta_{w t}=\frac{P_{w t}}{\dot{m} C_{p} \Delta T}
$$

\section{Results and Discussions}

For carrying out performance analysis of solar chimney, different heights of cylindrical chimney are selected. Various input parameters such as ambient temperature, inlet to outlet temperature difference, air density and maximum velocity of flow are recorded to compute different output parameters such as mass flow rate, efficiency of collector, efficiency of collector and efficiency of solar chimney are determined. Following graphs are drawn from the recorded readings. 


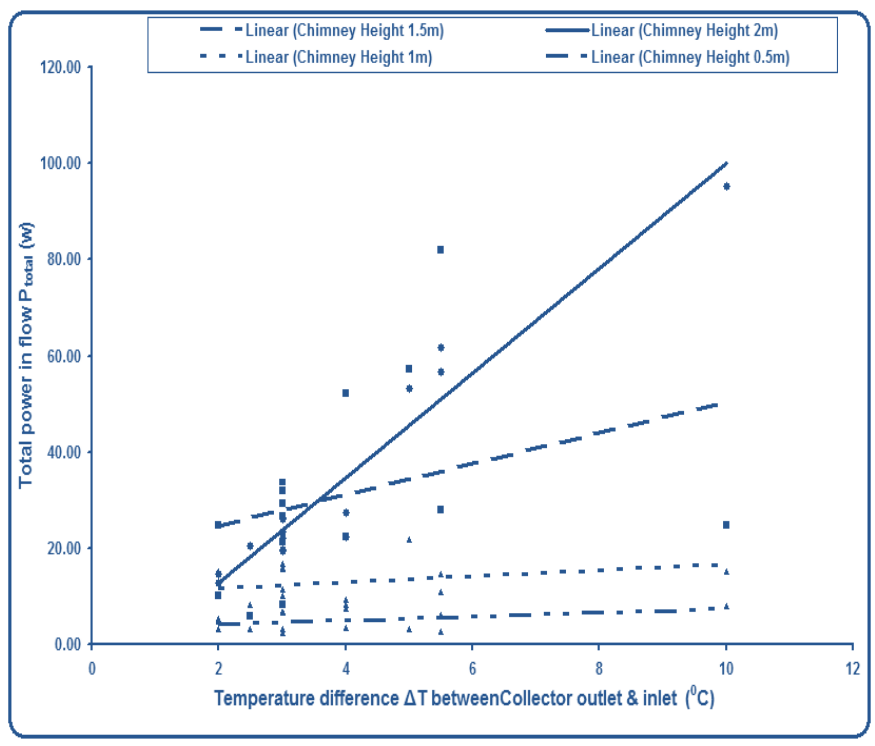

Fig. 4. Variation in total power Ptotal (w) with temperature difference $(\Delta \mathrm{T})$.

A) Variation in total power available in the flow Vs Temp. diff.

Variation of total power(w) with temperature difference $(\Delta T)$ between collector outlet and inlet is shown in Fig. 4.It clearly illustrates that the maximum power available increases almost

in linear proportion with $\Delta \mathrm{T}$, when $2 \mathrm{~m}$ high chimney is used. The maximum value of power is computed to be $95.2 \mathrm{w}$ and $85 \mathrm{w}$ with chimney height of $2 \mathrm{~m}$ and $1.5 \mathrm{~m}$ respectively when $\Delta \mathrm{T}$ is $10^{\circ} \mathrm{C}$. Here it is interesting to note that the available power rises steeply from $8.04 \mathrm{w}$ to $21.92 \mathrm{w}$, when $0.5 \mathrm{~m}$ high chimney is replaced with $1.0 \mathrm{~m}$ high chimney and further it rises sharply to $85.0 \mathrm{w}$ while using $1.5 \mathrm{~m}$ high chimney, but hereafter the rise is very small i.e. only $7.57 \%(7.2 \mathrm{w})$ while using $2.0 \mathrm{~m}$ high chimney as against the rise of $74.21 \%(63.08 \mathrm{w})$ when $1.0 \mathrm{~m}$ chimney is replaced with $1.5 \mathrm{~m}$ high chimney. This fact therefore underlines the concept of optimization of chimney height.

B) Variation in total power Ptotal (w) with the density at outlet of collector ( $\rho$ coll).

It can be seen from the Fig. 5. that at lower densities the total power available in the flow is higher. This is because of as the density decreases, pressure difference ( $\Delta$ Ptot) increases thereby increasing the draught at the chimney base, which subsequently increases the velocity of flow thereby increasing the total power available in the flow. 


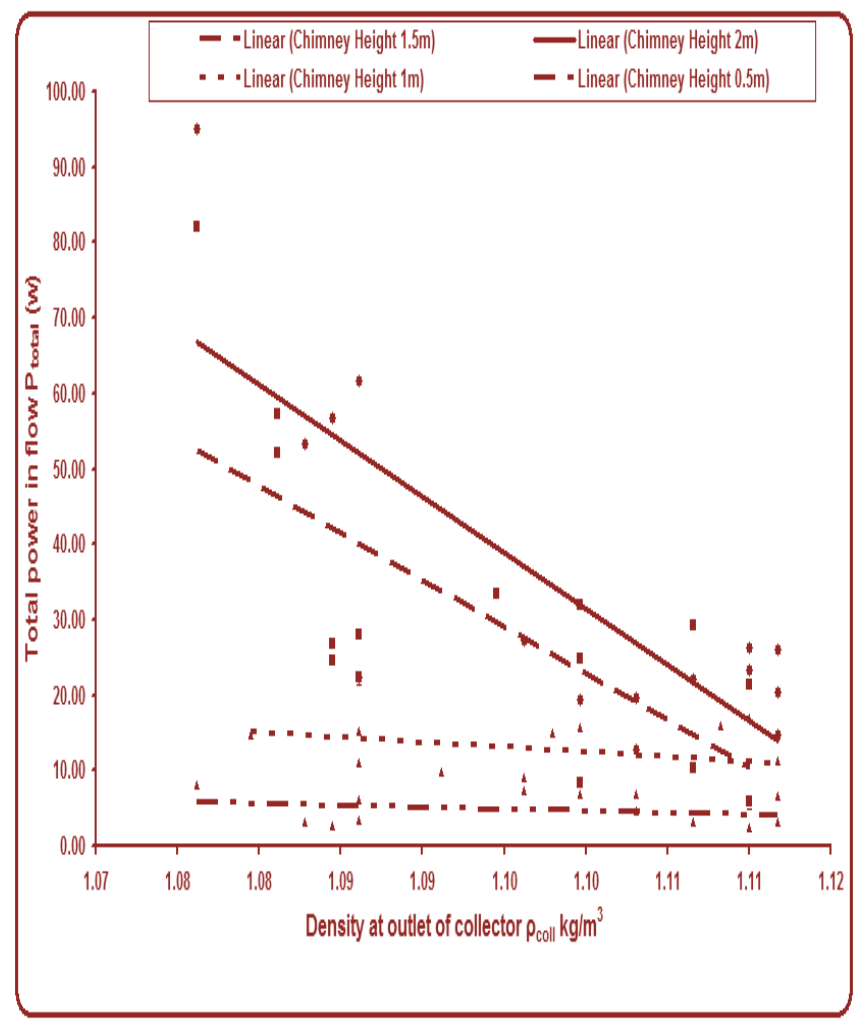

Fig.5. Variation in total power Ptotal (w) with the density at outlet of collector (

Variation in Total power Ptotal (w) with the maximum velocity at outlet of chimney (Vmax)

It is evident from the Fig. 6 . that at higher values of velocities the total power in the flow is higher. Figure also indicates that significant difference is not encountered in the total power while using $2 \mathrm{~m}$ high chimney as against $1.5 \mathrm{~m}$ chimney.

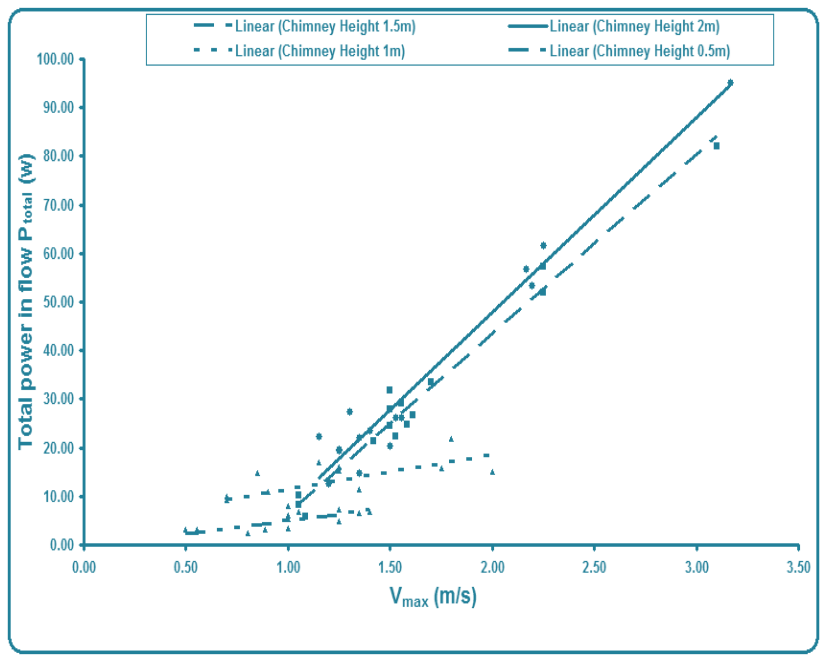

Fig.6. Variation in Total power Ptotal (w) with the maximum velocity at outlet of chimney (Vmax). D) effect of maximum velocity (Vmax) on actual power developed by the turbine.

A wide range of variation is observed in actual power while performing the experimentation throughout the day. Therefore, the trend of actual power produced by the turbine is depicted in the Fig. 7. The plot 
reveals that maximum power in the tune of $0.1 \mathrm{w}$ is produced by using $1.5 \mathrm{~m}$ high chimney, when the maximum velocity is observed to be $3.1 \mathrm{~m} / \mathrm{s}$ and also $0.08 \mathrm{w}$ is produced at maximum velocity of $2 \mathrm{~m} / \mathrm{s}$ by using $1.0 \mathrm{~m}$ high chimney. Interesting thing to note over here is that the trend line representing $2.0 \mathrm{~m}$ height chimney is producing the power equal to that of $1 \mathrm{~m}$ height chimney. The maximum power produced with $2.0 \mathrm{~m}$ high chimney is $0.08 \mathrm{w}$.

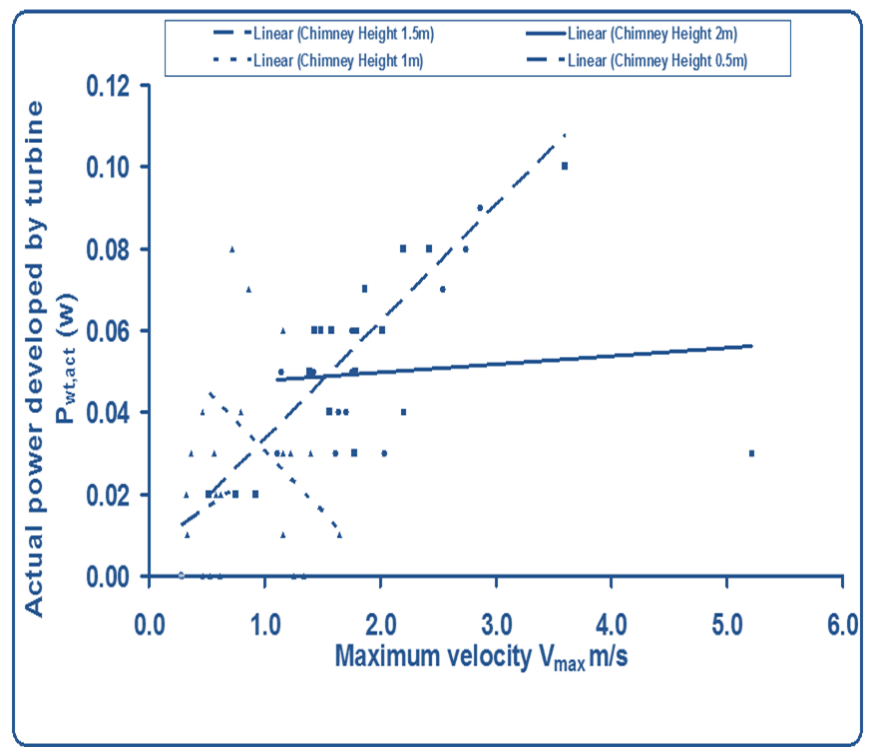

Fig. 7. Effect of maximum velocity (Vmax) on actual power developed by the turbine Pwt,act(w).

\section{Conclusion}

A small prototype of solar chimney was prepared for testing the viability of solar chimney. Four different heights of chimney; $05 \mathrm{~m}, 1.0 \mathrm{~m}, 1.5 \mathrm{~m}$ and 2.0 are selected. The following conclusion are drawn from result and discussions.

1) There is a optimum height for solar chimney. If the height increased beyond this height the power output increases with very less value. The concept of optimization is proved from this experimentation.

2) The total power is strongly correlated to decrease of density because as the density decreases which increase the pressure difference and increases the total power.

3) Total power depends on the higher value of velocity.

4) The actual power developed by the turbine is higher for $1.5 \mathrm{~m}$ high chimney as compared to $2.0 \mathrm{~m}$ high chimney

\section{References}

[1] R. K. Rajput, Power System Engineering. Firewall Media, 2006,pp.198.

[2] [8] R. Wengenmayr and T. Bührke, Renewable Energy. John Wiley \& Sons, 2011.

[3] C. Ngo and J. Natowitz, Our Energy Future: Resources, Alternatives and the Environment. John Wiley \& Sons, pp.184-186, 2009.

[4] C. M. Meyer -Towers of power-the solar updraft tower,l Docstoc.com. [online].Available:http://www.docstoc.com/docs/73010840/Towers-of-power---the-solar-updrafttower.

[5] W.Haff, G. Friedrich, Mayr, J.Schlaich, "Solar chimneys, part I: principle and construction of the pilot plant in Manzanares" International Journal of solar energy 2,pp 3-20,1983. 
[6] W. Haff,"Solar chimnes,Part II:preliminary test results from the Man-zanares pilot plant," International Journal of solar energy 2,pp141-161,1984.

[7] Z.D. Chen, P. Bandopadhayaya, J. Halldorsson, C. Byrjalsenb, P. Heiselberg, Y. Li, "An experimental investigation of a solar chimney model with uniform wall heat flux", Building and Environment, vol.38 pp. 893 - 906,2003.

[8] F. Denantes1, E. Bilgen, "Counter-rotating turbines for solar chimney power plants", Renewable Energy vol.31 ,pp.1873-1891,2006.

[9] Xinping Zhou, Jiakuan Yang, Bo Xiao, Guoxiang Hou, "Simulation of a pilot solar chimney thermal power generating equipment", Renewable Energy,vol.32 pp. 1637-1644,2007.

[10] Xinping Zhou, Jiakuan Yang, Bo Xiao, Guoxiang Hou, Fang Xing, "Analysis of chimney height for solar chimney power plant", Applied Thermal Engineering vol. 29 pp. 178-185,2009.

[11] Jorg Schlaich, Rudolf Bergermann, Wolfgang Schiel, Gerhard Weinrebe, "Design of Commercial Solar Updraft Tower Systems-Utilization of Solar Induced Convective Flows for Power Generation" ASME Journal of Solar Energy Engineering,vol.127,pp.117-124, 2005.

[12] A. Koonsrisuk, S. Lorente , A. Bejan, "Constructal solar chimney configuration", International Journal of Heat and Mass Transfer ,vol.53, pp. 327-333,2010.

[13] Fei Cao, Liang Zhao, Huashan Li, Liejin Guo," Performance analysis of conventional and sloped solar chimney power plants in China", Applied Thermal Engineering vol..50, pp.582-592, 2013.

[14] Fei Cao, Huashan Li, Liang Zhao, and Liejin Guo, Journal of renewable and Sustainable Energy 5, 021406 (2013); doi: $\quad$ 10.1063/1.4798434.

[15] Cristiana B. Maia, André G. Ferreira, Ramón M. Valle, Marcio F.B. Cortez, "Theoretical evaluation of the influence of geometric parameters and materials on the behavior of the airflow in a solar chimney", Computers \& Fluids ,vol. 38 ,pp.625-636, 2009.

[16] Alibakhsh Kasaeian, Mehran Ghalamchi, Mehrdad Ghalamchi, "Simulation and optimization of geometric parameters of a solar chimney in Tehran", Energy Conversion and Management vol.83 pp. 28-34,2014.

[17] Marco Aurelio dos Santos Bernardes, Theodor W. Von Backstrom, Detlev G. Kroger, "Analysis of some available heat transfer coefficients applicable to solar chimney power plant collectors", Solar Energy vol.83 pp. 264-275,2009.

[18] Shadi Kalash, Wajih Naimeh, Salman Ajib, "Experimental Investigation of a Pilot Sloped Solar Updraft Power Plant Prototype Performance Throughout a Year", Energy Procedia vol.50 pp.627 633, 2014.

[19] Peng-hua Guo, Jing-yin Li , Yuan Wang, "Annual performance analysis of the solar chimney power plant in Sinkiang, China", Energy Conversion and Management, vol. 87 pp. 392-399,2014.

[20] P.J. Cottam, P. Duffour , P. Lindstrand, P. Fromme, "Effect of canopy profile on solar thermal chimney performance", Solar Energy, vol.129 pp.286-296, 2016.

[21] Amel Dhahri, Ahmed Omri, A Review of solar Chimney Power Generation Technology, International Journal of Engineering and Advanced Technology, Vol.2, Issue-3, February 2013.

[22] Hussain H. Al-Kayiem, Ogboo Chikere Aja, "Historic and recent progress in solar chimney power plant enhancing technologies", Renewable and Sustainable Energy Reviews, vol. 8, pp.12691292, 2016.

[23] J. Schlaich, W Schiel, S Bergermann, Solar Updraft Towers, Elsevier2013, Stuttgart, Germany. 
[24] A.A. El-Haroun, Performance evaluation of solar chimney power plant in Egypt, Int. J. Appl. Sci. Technol., 13(2), 2012, pp. 49-59.

[25] Y.J. Dai, H.B. Huang, R.Z. Wang, Case study of solar chimney power plants in Northwestern regions of China, Renewable energy, 28(2003) 1295- 1304

[26] Miqdam T. Chaichan, Hussein A. Kazem, Thermal storage comparison for Variable basement kinds of a solar chimney prototype in Baghdad- Iraq weathers. 